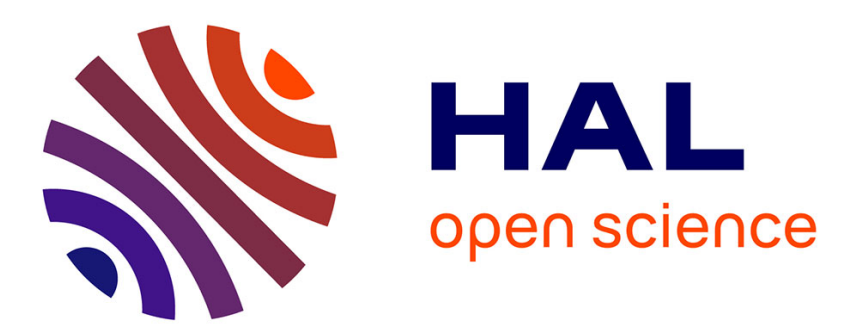

\title{
An efficient chemoenzymatic route to dihydroxyacetone phosphate from glycidol for the in situ aldoalse-mediated synthesis of monosaccharides
}

Franck Charmantray, Philippe Dellis, Soth Samreth, Laurence Hecquet

\section{- To cite this version:}

Franck Charmantray, Philippe Dellis, Soth Samreth, Laurence Hecquet. An efficient chemoenzymatic route to dihydroxyacetone phosphate from glycidol for the in situ aldoalse-mediated synthesis of monosaccharides. Tetrahedron Letters, 2006, 47, pp.3261-3263. 10.1016/j.tetlet.2006.03.036 . hal00022357

\section{HAL Id: hal-00022357 https://hal.science/hal-00022357}

Submitted on 26 Feb 2007

HAL is a multi-disciplinary open access archive for the deposit and dissemination of scientific research documents, whether they are published or not. The documents may come from teaching and research institutions in France or abroad, or from public or private research centers.
L'archive ouverte pluridisciplinaire HAL, est destinée au dépôt et à la diffusion de documents scientifiques de niveau recherche, publiés ou non, émanant des établissements d'enseignement et de recherche français ou étrangers, des laboratoires publics ou privés. 


\title{
An efficient chemoenzymatic route to dihydroxyacetone phosphate from glycidol for the in situ aldolase-mediated synthesis of monosaccharides
}

\author{
Franck Charmantray, ${ }^{\mathrm{a}}$ Phillipe Dellis, ${ }^{\mathrm{b}}$ Soth Samreth ${ }^{\mathrm{c}}$ and Laurence Hecquet ${ }^{\mathrm{a}, *}$ \\ ${ }^{a}$ Laboratoire SEESIB, UMR 6504 CNRS, Université Blaise Pascal, 24 Avenue des Landais, 63177 Aubière cedex, France \\ ${ }^{\mathrm{b}}$ Synkem S.A.S, 47, rue de Longvic, F-21300 Chenôve, France \\ ${ }^{\mathrm{c}}$ FournierPharma, 50, rue de Dijon, F-21121 Daix, France
}

Received 10 February 2006; revised 2 March 2006; accepted 7 March 2006

Available online 23 March 2006 Abstract-We report a new two-step procedure that uses inexpensive rac-glycidol to obtain valuable dihydroxyacetone phosphate
(DHAP), a building block for the synthesis of monosaccharide analogues.

(C) 2006 Elsevier Ltd. All rights reserved.

\section{Introduction}

Asymmetric framework construction by enzymatic carbon-carbon bond formation is an attractive alternative to conventional chemical methods. It offers stereochemical control, mild conditions and needs no protecting group. In the stereoselective synthesis of carbohydrates and carbohydrate mimetics, ${ }^{1,2}$ aldolases and in particular DHAP-utilising aldolases such as D-fructose-1,6-bisphosphate aldolase, D-tagatose-1,6bisphosphate aldolase, $\mathbf{L}$-fuculose-1-phosphate aldolase and L-rhamnulose-1-phosphate aldolase have proved to be useful catalysts. Enzymes of this family catalyse the aldol addition of dihydroxyacetone phosphate (DHAP) with a wide range of aldehydes to form a new $\mathrm{C}-\mathrm{C}$ bond, creating two hydroxylated stereogenic centres. D-Fructose-1,6-bisphosphate aldolase (FruA, EC 4.1.2.13), the aldolase most widely used for the synthesis of ketoses and analogues, produces an aldol adduct with $\mathrm{D}$-threo configuration. ${ }^{3}$ However, wider practical application of aldolases requires cheap and ready access to DHAP. The literature ${ }^{4}$ and our own earlier work ${ }^{5}$ has recently described efficient laboratory-scale chemical syn theses of DHAP. These strategies are made complicated by expensive or toxic reagents,

Keywords: DHAP; Multienzymatic synthesis; Aldolase; C-C Bond formation.

"Corresponding author. Tel.: +33 473 407871; fax: +33 473 407717; e-mail: Laurence.HECQUET@univ-bpclermont.fr multistep purification procedures and the need to protect functional groups. A promising alternative would be a short and inexpensive DHAP synthesis followed by an in situ aldolisation reaction catalysed by aldolase.

By this approach, DHAP was recently obtained by dihydroxyacetone (DHA) phosphorylation catalysed by DHA kinase with ATP. ${ }^{6}$ One drawback of this procedure was the need for a system of ATP regeneration from acetyl phosphate. Sheldon and co-workers ${ }^{7,8}$ also describe a coupled multienzymatic system to prepare carbohydrates from glycerol. The key step in this strategy was the efficient DHAP synthesis from L-glycerol3-phosphate (L-G-3-P) catalysed by L-glycerophosphate oxidase (L-GPO) in the presence of catalase. ${ }^{9}$ The authors elegantly prepared L-G-3-P by phosphorylation of glycerol with inexpensive pyrophosphate catalysed by phytase. However, the quantitative conversion of pyrophosphate into $\mathrm{D}, \mathrm{L}-\mathrm{G}-3-\mathrm{P}$ required a glycerol concentration of $95 \%(\mathrm{v} / \mathrm{v})$, restricting the synthesis to the hydrophobic carbohydrates.

Here we describe a short, practical and efficient chemoenzymatic synthesis of DHAP from inexpensive rac-glycidol (Scheme 1). Our two-step procedure was performed in one pot and successfully applied to the synthesis of 5-halo-D-xylulose mediated in situ by FruA. Our route was in four steps: (i) regioselective opening of the rac-glycidol epoxide ring with phosphate to generate D,L-G-3-P; (ii) oxidation of L-G-3-P in DHAP under 


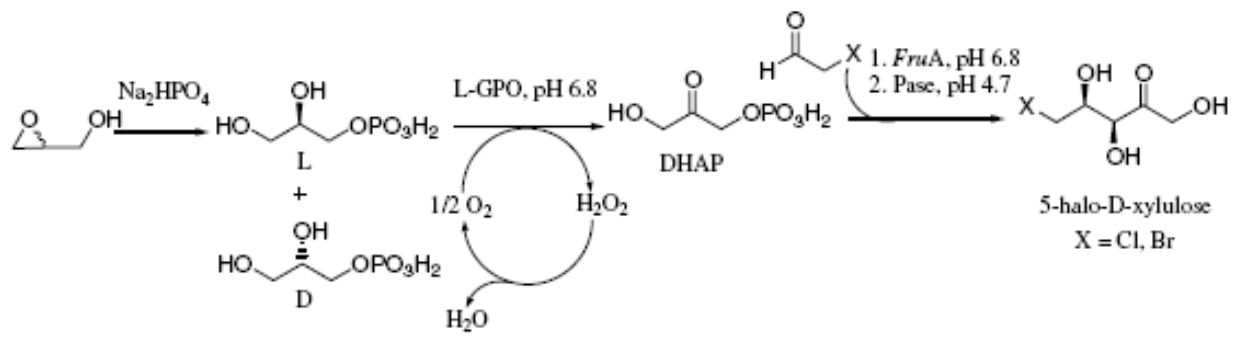

Scheme 1. Multienzyme system for one-pot 5-halo-D-xylulose synthesis.

oxygen mediated by L-GPO, coupled with hydrogen peroxide decomposition by catalase; (iii) FruA catalysed aldol addition of DHAP on 2-haloacetaldehyde, and (iv) 5-halo-D-1-phosphate hydolysis catalysed by acid phosphatase (Pase).

First step: The controlled opening of the rac-glycidol epoxide ring with various phosphate sources in refluxing water gave $\mathbf{D}, \mathbf{L}-\mathrm{G}-3-\mathrm{P}$ in moderate to good yields (Table 1). The reaction was monitored by $\mathrm{L}-\mathrm{G}-3-\mathrm{P}$ detection with L-GPO and subsequent assay for quantification of the hydrogen peroxide released ${ }^{10}$ (equal amounts of D-isomer were assumed to be formed). We showed that the opening of rac-glycidol was $\mathrm{pH}$-dependent with an optimum $\mathrm{pH}$ above 10 obtained with $\mathrm{Na}_{2}\left(\mathrm{~K}_{2}\right) \mathrm{HPO}_{4}$ and $\mathrm{Na}_{3} \mathrm{PO}_{4}$. In these cases, L-G-3-P was obtained in $50-60 \%$ yield (entries $1,2,4$ and 7 ). We also studied the influence of the counterion effect and the glycidol/ phosphate ratio. Similar results were observed when $\mathrm{K}^{+}$was replaced by $\mathrm{Na}^{+}$(entries 3 and 4 ). A threefold excess of rac-glycidol gave only a $5 \%$ increase in yield (entries 4 and 5). Surprisingly, the yield of D,L-G-3-P decreased when the concentrations of the two reagents increased (entries 4 and 6). For these reasons, we decided to use stoichiometric amounts of rac-glycidol and $\mathrm{Na}_{2} \mathrm{HPO}_{4}$ or $\mathrm{Na}_{3} \mathrm{PO}_{4}$ as phosphate sources (entries 4 and 7).

Second step: After conversion of glycidol into D, L-G-3-P in the presence of $\mathrm{Na}_{2} \mathrm{HPO}_{4}$ or $\mathrm{Na}_{3} \mathrm{PO}_{4}$, the $\mathrm{pH}$ was adjusted to 6.8 to optimise GPO activity. Catalase was added first (1200 units/mmol of L-G-3-P). The reaction was initiated by addition of L-GPO ( 30 units $/ \mathrm{mmol}$ of L-G-3-P). DHAP was assayed with NADH-consuming $\alpha$-glycerophosphate dehydrogenase. ${ }^{11}$ The behaviour of L-GPO was different when $\mathrm{Na}_{2} \mathrm{HPO}_{4}$ or $\mathrm{Na}_{3} \mathrm{PO}_{4}$ was

Table 1. Reaction conditions for D,L-glycerol-3-phosphate (D,L-G-3P) synthesis from rac-glycidol

\begin{tabular}{llllll}
\hline Entry $^{\mathrm{a}}$ & $\begin{array}{l}\text { rac-Glycidol } \\
(\mathrm{M})\end{array}$ & $\begin{array}{l}\text { Phosphate } \\
\text { source }\end{array}$ & $\begin{array}{l}\text { Phosphate } \\
\text { source (M) }\end{array}$ & $\mathrm{pH}$ & $\begin{array}{l}\text { D,L-G-3-P } \\
\text { Yield }\end{array}$ \\
\hline 1 & 0.5 & $\mathrm{H}_{3} \mathrm{PO}_{4}$ & 0.5 & 2 & 16 \\
2 & 0.5 & $\mathrm{KH}_{2} \mathrm{PO}_{4}$ & 0.5 & 4 & 26 \\
3 & 0.5 & $\mathrm{~K}_{2} \mathrm{HPO}_{4}$ & 0.5 & 10 & 50 \\
4 & 0.5 & $\mathrm{Na}_{2} \mathrm{HPO}_{4}$ & 0.5 & 10 & 55 \\
5 & 1.5 & $\mathrm{Na}_{2} \mathrm{HPO}_{4}$ & 0.5 & 10 & 60 \\
6 & 2.0 & $\mathrm{Na}_{2} \mathrm{HPO}_{4}$ & 2.0 & 10 & 42 \\
7 & 0.5 & $\mathrm{Na}_{3} \mathrm{PO}_{4}$ & 0.5 & 12 & 55 \\
\hline
\end{tabular}

${ }^{\mathrm{a}}$ Reaction carried out in refluxing water for $3 \mathrm{~h}$.

${ }^{\mathrm{b}}$ Yields were determined enzymatically. ${ }^{10}$ used in the previous step. In the latter case, whatever the quantity of L-GPO, the oxidation reaction stopped after a few minutes. By contrast, when $\mathrm{Na}_{2} \mathrm{HPO}_{4}$ was used, L-G-3-P was fully converted in to DHAP after oxidation by L-GPO. This two-step procedure from racglycidol gave DHAP in $28 \%$ overall yield (maximum theoretical yield was $50 \%$ ). This compound was thus readily available for in situ coupled aldol reaction.

Third step: FruA from rabbit muscle (RAMA) was added when the oxidation reaction with $\mathrm{L}-\mathrm{GPO}$ was complete. ${ }^{12}$ RAMA was used to catalyse the aldol addition of DHAP onto 2-chloroacetaldehyde (or 2-bromoacetaldehyde) leading to aldol adduct 5-chloro-D-xylulose-1-phosphate (or 5-bromo-D-xylulose-1-phosphate). The reaction was monitored by in situ ${ }^{13} \mathrm{C}$ and ${ }^{31} \mathrm{P}$ NMR (see Supplementary data). We observed total DHAP consumption and appearance of a single product. This compound was identified as 5-chloro-D-xylulose-1-phosphate (or 5-bromo-D-xylulose-1-phosphate) by its NMR signal at $\delta=68 \mathrm{ppm},{ }^{2} J=3.8 \mathrm{~Hz}$ for $\mathrm{C}_{5}$ carbon coupled with the phosphorus. The reaction yield was quantitative as determined by NMR.

Fourth step: The dephosphorylation of 5-chloro-D-xylulose-1-phosphate (or 5-bromo-D-xylulose-1-phosphate) was carried out by the addition of acid phosphatase (Pase) after adjusting the $\mathrm{pH}$ to 4.7 . The final products 5-chloro-D-xylulose (or 5-bromo-D-xylulose) were characterised as the major compounds in the reaction mixture, while glycerol was the sole by-product. This latter came from the hydrolysis of the phosphate group of D-G-3-P (obtained from D,L-G-3-P resolution catalysed by L-GPO in the second step) by Pase. After purification by column chromatography on silica gel, 5-chloro-D-xylulose and 5-bromo-D-xylulose were recovered as pure compounds in $47 \%$ and $12 \%$ yield, respectively, from $\mathbf{L}-\mathrm{G}-3-\mathrm{P}$.

In conclusion, we report an attractive two-step synthesis of DHAP from rac-glycidol, a cheap commercially available starting material. The controlled opening of the rac-glycidol epoxide ring with $\mathrm{Na}_{2} \mathrm{HPO}_{4}$ in water gave $\mathrm{D}, \mathrm{L}-\mathrm{G}-3-\mathrm{P}$ in $55 \%$ yield. $\mathbf{L}-\mathrm{G}-3-\mathrm{P}$ conversion to DHAP by means of L-GPO and catalase was found to be quantitative. We note that L-GPO and catalase could be co-immobilised as described earlier. ${ }^{13}$ We show that DHAP can be used in situ as a donor substrate of FruA in the presence of either 2-chloro- or 2-bromoacetaldehydes as acceptor substrates for the synthesis of either 
5-chloro- or 5-bromo-D-xylulose, suitable intermediates for the synthesis of substituted xylulose analogues in the $\mathrm{C}_{5}$ position. As DHAP aldolases display a broad specificity towards acceptor substrates, this four-step strategy can be generally applied to the synthesis of various analogues of monosaccharides.

\section{General procedure}

To a $10 \mathrm{~mL}$ solution of $r a c-2,3$-epoxypropanol $(0.38 \mathrm{~g}$, $5 \mathrm{mmol}$ ) in distilled water was added solid disodium hydrogen phosphate $\mathrm{Na}_{2} \mathrm{HPO}_{4}(0.74 \mathrm{~g}, 5 \mathrm{mmol})$. The mixture was heated at $100{ }^{\circ} \mathrm{C}$ for $3 \mathrm{~h}$, and assayed for L-G-3-P content. The yield was $55 \%$ from $(S)-2,3$-epoxypropanol (and 28\% from rac-2,3-epoxypropanol). After cooling to room temperature, the $\mathrm{pH}$ was adjusted to 6.8 with $3 \mathrm{~N} \mathrm{HCl}$ and $0.1 \mathrm{~mL}$ GPO/catalase mixture (45 units/1800 units), $70 \mu \mathrm{L}$ FruA from rabbit muscle (20 units) and 2-haloacetaldehyde ( $2 \mathrm{mmol}$ ) were successively added. The reaction proceeded with stirring at room temperature overnight. The $\mathrm{pH}$ was adjusted to 4.7 with $1 \mathrm{~N} \mathrm{HCl}$ and 50 units of acid phosphatase (Pase) was added. The reaction mixture was stirred for a further $24 \mathrm{~h}$ at room temperature. The $\mathrm{pH}$ was adjusted to 7.0 with $1 \mathrm{~N} \mathrm{NaOH}$, and $\mathrm{MeOH}(30 \mathrm{~mL})$ was added to the solution. The resulting precipitate was removed by filtration through Celite. The filtrate was concentrated under vacuum and the residue then underwent silica gel chromatography with cyclohexane/ AcOEt (2:8) as an eluent. 5-Chloro-D-xylulose was recovered in $47 \%$ yield and 5-bromo-D-xylulose in $12 \%$ yield.

\section{Acknowledgements}

We thank Fournier Pharma, for financial support.

\section{Supplementary data}

Supplementary data for ${ }^{31} \mathrm{P}$ and ${ }^{13} \mathrm{C}$ NMR spectra associated with this article can be found, in the online version, at doi:10.1016/j.tetlet.2006.03.036.

\section{References and notes}

1. (a) Gijsen, H. J. M.; Qiao, L.; Fitz, W.; Wong, C.-H. Chem. Rev. 1996, 96, 443-474; (b) Wymer, N.; Toone, E. J. Curr. Opin. Chem. Biol. 2000, 4, 110-119.

2. (a) André, C.; Guérard, C.; Hecquet, L.; Demuynck, C.; Bolte, J. J. Mol. Catal. B, Enzym. 1998, 5, 459-466; (b) Crestia, D.; Guérard, C.; Veschambre, H.; Hecquet, L.; Demuynck, C.; Bolte, J. Tetrahedron: Asymmetry 2001, $12,869-876$.

3. Brockamp, H.; Kula, M. Appl. Microbiol. Biotechnol, 1990, 34, 287-291.

4. Meyer, O.; Rohmer, M.; Grosdemange-Billiard, C. Tetrahedron Lett. 2004, 45, 7921-7923.

5. Charmantray, F.; El Blidi, L.; Gefflaut, T.; Hecquet, L.; Bolte, J.; Lemaire, M. J. Org. Chem. 2004, 69, 93109312.

6. Sánchez-Moreno, I.; García-García, J. F.; Bastida, A.; García-Junceda, E. Chem. Commun. 2004, 14, 1634 1635.

7. Schoevaart, R.; van Rantwijk, F.; Sheldon, R. A. Chem. Commun. 1999, 24, 2465-2466.

8. Schoevaart, R.; van Rantwijk, F.; Sheldon, R. A. J. Org. Chem. 2000, 65, 6940-6943.

9. Fessner, W.-D.; Sinerius, G. Angew. Chem., Int. Ed. Engl. 1994, 33, 209-212.

10. Bergmeyer, H. U. In Methods in Enzymatic Analysis; Verlag Chemie, 1984; Vol. 4, pp 342-350.

11. Bergmeyer, H. U. In Methods in Enzymatic Analysis; Verlag Chemie, 1984; Vol. 2, pp 146-147.

12. The concomitant reactions of oxidation and aldolisation were slightly less yield effective.

13. Krämer, L.; Steckhan, E. Tetrahedron 1997, 53, 14645 14650 . 